\title{
Relationship Lending and Its Effects on Transaction Cost of Obtaining Credit. The Case of Maize Farmers in Ghana
}

\author{
Stephen Antwi* Kwasi Ohene-Yankyira \\ Department of Agricultural Economics, Agribusiness and Extension, Faculty of Agriculture, College of Agriculture and Renewable \\ Natural Resources, Kwame Nkrumah University of Science and Technology, Kumasi Ghana \\ *Corresponding author: santwi53@yahoo.com
}

\begin{abstract}
This paper investigates the effects of relationship lending on the transaction costs of obtaining credit from financial institutions by maize farmers in Ashanti and Brong Ahafo regions of Ghana. A survey 380 farmers from five and three districts respectively in Brong Ahafo and Ashanti regions of Ghana was employed to gather the data used in this study. Multi-stage purposive and randomized sampling technique was used to sample the maize farmers. Descriptive statistics were used to evaluate transaction costs and socio-economic characteristics of the respondents while multiple regression analysis was used to measure the effects of relationship lending on transaction costs of maize farmers when taking credit facilities. The transaction cost model was estimated using OLS regression. Similar to many financial institutions operating in other developing countries, access to a loan in Ghana imposes high transaction costs upon mostly poor rural households who are engaged in maize production and sale. The results showed that access to financial information, prompt repayment of loans when it falls due and having investments with banks have the tendency to reduce the transaction cost of obtaining credit by farmers significantly. Also keeping non mandatory savings and increase in the number of years of dealing with the bank have the likelihood of reducing transaction cost of borrowing. However dealing with multiple banks increases the transaction cost for the farmer. Thus, any policy aimed at improving farmer-banker relationships would significantly reduce the farmers transaction cost of borrowing.
\end{abstract}

Keywords: transaction cost, relationship lending, agricultural credit, information asymmetry, Brong Ahafo and Ashanti Region, Ghana

Cite This Article: Stephen Antwi, and Kwasi Ohene-Yankyira, "Relationship Lending and Its Effects on Transaction Cost of Obtaining Credit. The Case of Maize Farmers in Ghana.” Journal of Finance and Economics, vol. 5, no. 2 (2017): 38-49. doi: 10.12691/jfe-5-2-1.

\section{Introduction}

Maize is an important food crop in Ghana, accounting for more than $50-60 \%$ percent of the country's total cereal production [40]. According to [20], about 2.5 million households harvested maize in 2005 in Ghana. After cocoa, maize is the second largest commodity crop produced in the country [37].

The Ghana Grains Development Project (1979-1997) and the Food Crops Development Project (2000-2008) made major investments to improve maize yield.

Despite these efforts, the average maize yield of 1.5 t/ha under traditional production methods and rain fed conditions in Ghana, still remains lower compared to the average maize yield in Africa of1.7 t/ha, and that of Thailand and southern Mexico [37].

Indeed, the shortfall in the production of the maize adversely affects a lot of families in the form of income, employment and food security [39]. Also the farmers in the poultry industry have to import expensive yellow maize to feed their birds, due to their inability to meet that demand locally [37].

Factors such as the use of low quality seeds ,soil moisture stress due to drought, unsuitable crop husbandry practices such as late planting, poor weed management, pest and disease attacks [40] among others have been identified to explain the production gap [37]. However, lack of access to credit has been seen to be the greatest factor [11]. Hence [5] argues that if households get access to credit, it opens up productive opportunities, creates jobs and increases the incomes of farmers. This means maize farmers' access to credit will help bridge the gap [44].

Thus many governments in developing countries initiated credit programs with the idea that more credit could be allocated to rural smallholder farmers [12].

Despite these developments, only $4.7 \%$ of credit from the Deposit Money Banks went to the Agriculture, forestry and fishing sectors in 2012 [41]. Also only 9\% rural households have access to credit from formal financial institutions [21].

This means small scale farmers have mostly been locked out of credit allocation system from financial 
institutions. This may partly be due to the lack of acceptable collateral, high administrative costs and perceived high risks associated with agricultural and small scale farmers [3]. But agricultural household models suggest that farm credit is not only impeded by the limitations of self-finance, but also, by uncertainty pertaining to the level of output and the time lag between inputs and output [13].

The inability of the farmers to provide information about their activities has been seen as the major reason why the banks are not willing to provide credits to the farmers [55]. Thus information asymmetry is a challenge in agricultural credit delivery [3].

According to the [58], many transactions involving credit to the agricultural sector in developing countries such as Ghana involve high transaction cost because of information asymmetry. The difficulty in getting information about the activities of the farmers when it comes to agricultural finance imposes transaction cost upon them [10]. Thus transaction cost in credit can be grouped into two: the transaction cost incurred by the financial institutions who supply the credit and the transaction cost incurred by the borrowers (farmers) who demand the credit.

Farmers in their bid to access credit incur transaction cost. Borrower transaction costs which is the focus of this study, mainly involve various charges imposed by lenders beyond payments of interest [56]; [36]. Borrower transaction costs are borne by the borrower in each step of the credit receiving and repayment process. Such transaction cost may be seen in the travelling cost incurred by the borrowers in visiting the banks. By leaving their businesses to spend time at the banks, the borrowers also incur opportunity cost. Other cost such as paper cost, legal, collateral or guarantee, controlling and other cost may also be incurred by the borrowers [26].

According to [29], relationship lending and the relevant governance structure are some of the mechanisms by which transaction cost in the economic exchange of goods and services among agents can be reduced.

Relationship lending is defined as the long-term close ties between a financial institution and a borrower that goes beyond the execution of simple, anonymous, financial transactions [48]. Relationship lending is a lending technology in which the financial institution bases its credit decisions in substantial part on proprietary information about the borrower through a variety of contacts over time. Through the establishment of long term relationships between a bank and a client (farmer), soft information is acquired over time and this information helps the bank to determine the character, reliability, and trust of a the farmer when it comes to lending to the farmer [44].

Relationship between borrowers and banks is measured in part through the provision of loans [6], Duration (years) of account operation [48] deposits, investments, other financial products [8] multiple banking relationships [6], and the borrower's ability to get information from the officers of the bank [27].

There are several empirical studies that have considered lending and transaction cost of borrowing in developing countries [1,2,9,14,23,49,51]. Some of these studies have assessed the transaction costs, while others have focused on the effects of these costs on lenders and borrowers. Researchers have presented evidence that many lenders impose high transaction costs on their borrowers because of information asymmetry in the credit market involving farmers $[1,45,46]$.

Other empirical studies have recounted the concerns of farmers regarding the borrowing transaction costs in developing countries [31,50,60,61]. The majority of empirical studies are in agreement that the relatively heavy transaction costs inhibit the access to credit by the small farmers $[1,18,34,51]$. A lack of credit availability, as a result of high transaction costs, has been reported in some empirical studies in agricultural sector in Iran $[25,26]$.

Despite several empirical studies on transaction costs, there is little data available on how relationships between borrowers (farmers) and lenders (banks) can affect the transaction costs incurred by borrowers especially maize farmers in Ghana. In other words, empirical work on how relationship lending affects transaction cost of borrowers is lacking and thus needs to be filled.

This study is intended to provide an in depth analysis of the transaction costs incurred by farmers when obtaining credit from formal and semiformal institutions, and how these transaction cost borne by the borrower in each step of the credit accessing process could be affected by relationship lending in Ghana.

It is expected that relationship lending measured by the observable factors such as duration of account operation, prompt loan repayment, deposit or investment level of the farmer and the farmers ability to get information from the bank will have negative effects on the transaction cost of borrowing. However dealing with multiple banks is expected to increase transaction cost for the farmer.

The contribution of this study to knowledge is based on the premise that maize farmers' inability to access formal credit from financial institutions is influenced by information asymmetry. Previous studies in the field of relationship lending has focus primarily on well structured firms such as privately owned companies, partnership or sole proprietorship firms whose financing sources are limited to banks and trade credit and less on agriculture entrepreneurs whose activities are not formal, uncoordinated and individualized especially in developing countries like Ghana.

Furthermore, current studies in relationship lending often consider the supply side of credit delivery at the expense of the demand side, by relying on the credit files of the banks $[6,8,47]$ to determine the effect of relationship lending on transaction cost incurred by borrowers. This study fills this gap by employing primary data, gathered through survey instrument from maize farmers and key informants (relationship/credit officers and management members of financial institutions) to access the effects of relationship lending on transaction cost incurred by maize farmers when accessing credit from formal financial institutions.

To the best of our knowledge Studies on the borrower transaction cost in most cases do not consider the effects of relationship factors such as the number of banks the borrower deals with, repayment behavior of the borrower, investment and deposit held by the borrower and others $[27,46,30]$. The study fills this gap by looking at how 
banker- farmer relationships affect the transaction cost the borrower incurs when taking credit from the financial institutions.

Finally, applying the Ordinary Least Square (OLS) regression model on borrower transaction cost as used by previous studies $[27,30,46]$ can results in massive problems of non-linearity among variables. Hence, this study further academic knowledge by using the double log functional form to estimate the borrower transaction cost model. The adopted model does not only eliminate the problems of non-linearity among variables but also helps to interpret coefficients of dummy variables and coefficients considered as elasticity.

The remainder of the paper is organized as follows. Section 2.1 reviews the Literature on relationship lending while section 2.2 captures the conceptual framework of borrower transaction Cost. Section.3. describe the data and Methodology used in the empirical analysis, while section 4 presents the results and discussion. Conclusion and policy implication of the study appears in Section 5.

\section{Literature Review and Conceptual framework}

\subsection{Literature Review}

According to [33], transaction cost is mostly caused by transaction frictions and information asymmetry. That is lenders do not have complete information with respect to the characteristics of potential borrowers. Financial institutions need information about the business and the borrowing behavior of the borrower in order to assess the profitability of the business and the credit worthiness of the customer before loans are approved and disbursed. In a situation where there is information gap, lenders may reduce the loan size (credit ration) or may not be interested in granting the loan at all and this brings about a mismatch in economic interest of borrowers and lenders [7].

When there is information gap, financial institutions become more actively involved in monitoring the activities and the behavior of firms since the level of trust at this level is very low and this increases cost [33]. More to the point, financial institutions design extensive loan contracts which include the use of eternal institutions like the courts to ensure that terms and agreements in the contracts are adhered to. Furthermore, well trained loan officers are needed for effective monitoring and enforcement of the contract [57].

That explains why, opined that the loan disbursement process becomes very expensive when there is information gap since more resources are technically required than when there is easy access to client information.

The existence of transaction cost means borrowers receive small size but costly loan. Also financial institutions have to go through the hectic bureaucratic procedures to verify and register collaterals and other financial documents [57].

Transaction cost in recent research, has been seen as one of the major causes of high cost of funds to borrowers [22] and this has been found to be responsible for the high lending interest rate in Africa [16].

It has been suggested that, relationship lending and the relevant governance structure are some of the mechanisms by which frictions in the economic exchange of goods and services among agents can be reduced [36].

This is because as a financial institution continues to deal with a borrower, the bank gets more information about the client with regards to the profitability and creditworthiness of the client [8].

Lenders have an incentive to utilize greater relationships in the lending process to take advantage of the information generated in the process and the resultant reduction in monitoring. On the other hand, loyal borrowers are given the opportunity to establish the necessary reputation required for loan availability and accessibility [47].

Further, because it is not necessary to undertake explicit contracting in relationship lending [8], bureaucratic procedures associated with verification of documents and collateral requirements are reduced. The establishment of relationships not only increases the level of trust of loyal customers of a lending institution, but also creates a basis for lenders to establish the knowledge about the behavior of their borrowers so that they can more accurately predict the repayment capabilities of their clients. Thus relationship lending that comes through trust, can reduce transaction cost by eliminating both ex ante and ex post opportunism [44]. Consequently trust mitigates adverse selection and moral hazards, reduces screening and monitoring cost which leads to a reduction in the transaction cost. Thus Relationship variables, such as, previous loan repayment, Duration (years) of account operation, deposits, investments and the borrower's ability to get financial information from the officers of the bank are expected to reduce the transaction cost of the farmer while multiple banking relationships is expected to increase the transaction cost for the farmer.

\subsection{Conceptual Framework of Borrower Transaction Cost}

Before a borrower can have the credit, he has to travel from his home or business centre (farm) to visit the bank and this involves traveling costs. Thus the first cost incurred by the borrower or the farmer is travelling cost (Table 1). The farmer leaves his work and spends time at the bank in order to process the loan. This involves an opportunity cost since that time spent at the bank could have been channeled into other productive ventures. The average labour cost when employed for a day was used to calculate the opportunity cost the farmer incurs. At the bank, the farmer also has to pay for the application forms needed to be completed for the loan application. In addition, he has to provide passport pictures and photocopies of his supporting documents such as identity cards and registration forms. This cost is known as Paperwork costs.

The borrower also incurs Office or legal costs which consist of Legal fees paid to law firms, attorneys, and public offices. Farmers have to spend money to register their farms especially.

Guarantee and collateral costs are the Costs incurred for securing the loan before the credit is issued. Borrowers have to convert the ownership of their assets being used as collateral to the bank and this involves cost. Guarantors have to be transported and fed when being sent to the banks to guarantee for the loans. 
Table 1. Components of Borrower Transaction cost

\begin{tabular}{|c|l|l|}
\hline Number & Components of transaction cost & Definition \\
\hline $\mathbf{1}$ & $\begin{array}{l}\text { Processing \&application fee and other paper } \\
\text { work }\end{array}$ & $\begin{array}{l}\text { Processing fees, application fees,cost of photocopies of documents, getting } \\
\text { pictures, obtaining personal documents and others }\end{array}$ \\
\hline $\mathbf{2}$ & Transportation cost & $\begin{array}{l}\text { The Costs incurred by farmers when visiting } \\
\text { The financial institution }\end{array}$ \\
\hline $\mathbf{3}$ & Collateral and guarantee cost & $\begin{array}{l}\text { Costs incurred on the security used(converting ownership) and expenses on } \\
\text { guarantors }\end{array}$ \\
\hline $\mathbf{4}$ & Legal Cost (GHథ) & Legal fees charged by the financial institutions \\
\hline $\mathbf{5}$ & Monitoring and supervision cost & $\begin{array}{l}\text { Costs imposed on borrowers for the control and monitoring (supervision) of their } \\
\text { credit by credit officers and managers }\end{array}$ \\
\hline $\mathbf{6}$ & Opportunity cost & $\begin{array}{l}\text { Total cost of the time spent in processing the credit. This time could have been } \\
\text { converted into other productive ventures. }\end{array}$ \\
\hline $\mathbf{7}$ & Other Cost & $\begin{array}{l}\text { Other cost incurred in the process of obtaining credit example tips and } \\
\text { appreciations to officers }\end{array}$ \\
\hline $\mathbf{8}$ & Total transaction cost & \begin{tabular}{l} 
Summation of the above \\
\hline
\end{tabular} \\
\hline
\end{tabular}

Borrowers also incur expert and controlling (supervision) costs when theyapply and/or receive approval for the loans. These are the costs imposed on borrowers for the control and monitoring (supervision) of their credit by experts such as loan officers and the managers. Finally the borrowers incur other costs in the process of obtaining credit such as tips and the showing of appreciations to credit officers and tellers.

Thus the total transaction costs of obtaining a loan is the summation of the above, when the bank-customer relationship becomes intense.

\section{Research Methodology}

\subsection{Study Area}

The study area consists of two administrative regions in Ghana, Ashanti and Brong Ahafo. The area occupies a total land area of 63,946 square kilometers and is centrally located in the middle belt of the country. The area lies between longitude $0.15 \mathrm{~W}$ and $2.25 \mathrm{~W}$ and latitude 5.50 and 7.46 north of the equator. The population of the study area is about $7,091,363.00$ representing about $28.75 \%$ of the national population [21]. The annual average rainfall ranges between $1000 \mathrm{~mm}$ and $1400 \mathrm{~mm}$. The rainfall pattern is bimodal; the major rainy season starts in March, with a minor peak in August tapering off in November.

The study area has a tropical climate with high temperatures averaging $23^{\circ} \mathrm{C}$ [20]. Agriculture and related work is the major occupation in all the districts within the study area, though the level and intensity as well as farming systems vary between districts. The proportion of working population engaged in agriculture and agriculture related activities in Brong Ahafo Region ranges from a low of $65.7 \%$ in Sunyani to a high level of $83.0 \%$ in Sene District. In Ashanti Region it ranges from $45 \%$ in Kumasi Metropolitan area to about 82\% in Adansi West and East Districts [19].

\subsection{Sampling Techniques}

The sample was selected in three (3) stages; first, was the purposive selection of regions followed by the purposive selection of districts. Agricultural activities guided the selection of the two regions while the districts were selected based on the level of maize production using official statistics from [42]. After a consideration of the objectives of the study and time and resources available, eight (8) districts were selected including three from Ashanti Region and five from Brong Ahafo Region. In Ashanti Region the districts whose (EjuraSekyedumase, Asante Akim North Offinso North) maize output in 2012 exceeded 15,000 metric tonnes, were selected. The Five districts (Dormaa, Nkoranza North, Sunyani west , Sunyani west, Techiman Kintampo North) selected in Brong Ahafo Region had a minimum of 30,000 metric tonnes of maize output in 2012 [42]. The third stage of the sampling involved the identification and listing of the communities and the maize farmers in the operational area. This was undertaken with the help of Agricultural Extension Agents (AEAs) in charge of the operational areas in each of the selected districts. A full list of all the maize farmers; both those who had an account with financial institutions and those who did not have accounts were taken from the extension officers. Because the emphasis of this research is on how relationships affect access to credit and credit can only be obtained when the farmer has an account, those who did not have accounts were purposely exempted. From the list of farmers who had an account, a sample was selected through the following process. The name of each farmer was written on a piece of paper and properly folded. The folded papers containing the names were thoroughly mixed in a bowl. The folded paper was then randomly picked one at a time from the bowl until the needed sample size for the district was reached.

To obtain the total number of respondents, the estimation method given by [4] was used. The method is as follows:

$$
n=\frac{s^{2}(x)(y)}{(E)^{2}}
$$

Where $n=$ Sample size, $x=$ the proportion of the population who have access to credit, $y$.= the proportion of the population who do not have access to credit, $S=$ Number of standard deviation for a chosen confidence interval level, $E=$ The allowable margin of error

According to GLSS6 report, on an average,45\% of individuals living in rural areas, at least save with one of the following financial institutions; Commercial banks, Rural banks, Savings \& loans companies and cooperative 
credit unions and thus have the possibility of getting access to credit [21]. Thus, assuming 95\% confidence level and 5\% margin of error,

$$
n=\frac{1.96^{2} \times 0.45 \times 0.55}{0.05^{2}}=380 .
$$

Therefore 380 farmers were sampled for the study. However 308 applied for loans. Apart from the sampled maize farmers, the study also interviewed representatives of the financial institutions mostly used by the farmers operating within the selected districts to get their views on the role of relationship lending on credit delivery to farmers. The respondents from the financial institutions were made up of Credit officers, Relationship officers and managers who are in charge of credit delivery in the financial institutions.

\subsection{Data Collection}

Data used in this research were actually not readily assembled, quantified, and condensed as can be found in the use of secondary sources (such as credit report of banks, census reports and internet-based resources). Primary data was used in this study and it was collected from two main sources namely, maize farmers and key informants (relationship/credit officers and management members) from a selected number of financial institutions in the study area. Data and information were collected through survey. A combination of individual interviews and questionnaires were used. Structured questionnaire as well as interviews were used to collect data from the maize farmers and financial institutions in the study area. SPSS was used for the data Entry but was transferred to STATA for the analysis to be made

\subsection{Assessment of Transaction Costs}

Borrowing transaction costs include all the costs other that interest costs that are incurred by farmers in the course of obtaining the credit. This means the total cost the borrower incurs on the credit obtained, is the sum of sum of all the financial costs, that is interest payment and the transaction costs incurred. This is given by

$$
\mathbf{T C C}=\mathbf{I C}+\mathbf{T C}
$$

Where

TCC is the total cost on credit obtained.

IC stands for the interest cost, and

TC is the transaction costs.

The transaction cost aspect of the total credit cost incurred by farmers is our concern. To assess the transaction costs, there is the need to identify and classify the sources of transaction cost the farmers incur. The costs on each classification are also determined.

Per the conceptual framework above the transaction costs were classified and defined into seven categories according to the kind of expenditure needed to be made to meet requirements. These categories are traveling costs, opportunity costs, paperwork costs, office (legal) costs, legal fees, guarantee and collateral costs, expert and controlling costs and other costs.

The transaction costs can be expressed as a percentage of the loan amount, or as a percentage of the interest rate and as a percentage rate comparable to an annual interest rate.

\subsection{Empirical Model Specification for Transaction Cost}

The relationship between transaction cost and its determinants, including the relational variables, can be expressed in a relation as follows:

$\mathrm{TC}_{\mathrm{i}}=\mathrm{f}(\mathrm{Zi})$ Where TCi is the Transaction Costs Measure for ith transaction and $\mathrm{Zi}$ is a matrix of explanatory variables that affect the measures in addition to the relational factors.

To estimate the effects of relationship lending on transaction cost incurred by maize farmers, a double-log functional form was applied following [27] and [30].

The empirical model is specified as

$$
\begin{aligned}
& \text { InATTC }=\beta_{0}+\beta_{1} \ln A G E+\beta_{2} \text { GEN }+\beta_{3} \text { EDUC } \\
& +\beta_{4} \operatorname{lnASSETV}+\beta_{5} \ln \text { DISTANCE }+\beta_{6} \operatorname{lnLOANZ} \\
& +\beta_{7} \text { FAINFO }+\beta_{8} \text { MEMBER }+\beta_{9} \text { INVESTMT } \\
& +\beta_{10} \text { MULTYBANKS }+\beta_{11} \text { PRELOAN }+\beta_{12} \text { OINCOME } \\
& +\beta_{13} \text { LDURATION }+\beta_{14} \text { YRSINFARM } \\
& +\beta_{15} \operatorname{lnLOANINT}+\beta_{16} \operatorname{lnFDEBT}+\varepsilon
\end{aligned}
$$

Where $\beta_{0}$ is the intercept while $\beta_{1}-\beta_{16}$ are the coefficients to be estimated. ATTC is the transaction cost incurred by maize farmers (borrowers).

AGE is the age of the farmer measured in years, GEN represents Gender which is a dummy variable; which takes the value 1 if the farmer is male and 0 0therwise, EDUC is a continuous variable which represents education in years of the farmer. LnASSETV represents the natural log of Asset value of the farmer measured in Ghana Cedis,. InDISTANCE represents the natural log of distance to lending institution Measured in kilometers, and LOANZ is the Loan size measured in Ghana cedis. FAINFO represents Information about financial services available to the farmer. It is measured by the farmer's ability to interact with the staff of the financial institution to get information thereby bringing them closer. It takes the value 1 if the farmer is able to get financial information from the banking staff and 0 otherwise MEMBER represents whether he farmer is a member of Cooperative/social organization. It is also a dummy variable which takes the value one if yes $=1$, and zero otherwise. OINCOME represents the other income the farmer gets other than from maize. INVESTMENT represents investment in the form of fixed deposit held by the farmer. This is a dummy variable which takes the value 1 if the farmer has Fixed deposit/investments and zero otherwise. MULTYBANKS is a continuous variable which captures the farmer's relationships with multiple financial institutions. The smaller the number of financial institution the farmer deals with, the better. PRELOAN represents the repayment of previous loan taken by the farmer from his main bank or other bank. It takes the value 1if the farmer was able to pay off his loan within a maximum of 30 days when the repayment date falls due and zero otherwise. How long the farmer has been operating his account is also represented by LDURATION. Interest on loan is captured by LOANINT. Finally to be able to consider experience, how long the farmer has been farming is also captured with YRSINFARM. 
Table 2. Relationship variables and their measurements.

\begin{tabular}{|c|c|c|}
\hline \multicolumn{3}{|c|}{ Operational Definitions of the Relationship Variable } \\
\hline Variable name & SYMBOL & Definition \\
\hline \multicolumn{3}{|l|}{ Relationship variables } \\
\hline Duration & LDURATION & $\begin{array}{l}\text { It is a continuous variable which measures the duration in years the farmer has operated his } \\
\text { accounts with the financial institution }\end{array}$ \\
\hline Savings & SAVINGS & 1 if maintained a non-mandatory savings account and 0 otherwise \\
\hline Investment & INVESTMENT & 1if the farmer has fixed deposit with the bank and 0 otherwise \\
\hline $\begin{array}{l}\text { Previous Loan Repayment } \\
\text { Behavior }\end{array}$ & PRELOAN & $\begin{array}{l}1 \text { if the farmer was able to pay off his loan within a maximum of } 30 \text { days when the } \\
\text { repayment date falls due and zero otherwise }\end{array}$ \\
\hline $\begin{array}{l}\text { Farmers Access To Financial } \\
\text { Information }\end{array}$ & FAINFO & $\begin{array}{l}\text { It takes the value } 1 \text { if the farmer is able to get financial information from the banking staff } \\
\text { and } 0 \text { otherwise. }\end{array}$ \\
\hline $\begin{array}{l}\text { Multiple Banking } \\
\text { Relationships }\end{array}$ & MULTYBANKS & $\begin{array}{l}\text { It is a continuous variable which captures the farmer's relationships with multiple financial } \\
\text { institutions. The smaller the number of financial institution the farmer deals with, the better }\end{array}$ \\
\hline
\end{tabular}

\subsection{Analytical Techniques for the Transaction Cost}

In the first place Descriptive statistics using means was used to analyze the characteristics of transaction costs which include all the costs other than interest rate costs that are incurred by the borrower. Secondly To analyze the factors including the relational factors, which affect transaction costs, the data obtained were, fitted by means of the ordinary least squares (OLS). Other writers used four functional forms of linear, exponential, double log and semi $\log$ to specify the relationship between transaction costs and each of the variables. But the double log functional form was adopted based on certain econometric criteria such as, to be able to interpret the coefficients as elasticity, avoid the problems on nonlinearity in variables and be able to interpret the coefficients of the dummy variables as percentage.

\section{Results and Discussion}

\subsection{Socioeconomic Characteristics and Sample Statistics}

Table 3 shows the distribution of maize farmers who were considered for the study in the study area. They borrowed for various reasons in the study. The results show that majority of the respondents are males (72\%) indicating that more males maize farmers are interested in taking loans than their female counters in the study area. Men are more expected to have more likelihood to reduce transaction cost than the females. The male dominance in maize production is also confirmed by [4]. The results also show that male household heads are dominant (85\%) across the two study regions. The male household-head dominance in this study is similar to the $80 \%$ male household-heads reported in a recent nation-wide survey by the [15], and $71.8 \%$ in rural forest reported in Ghana Living Standard Survey (GLSS6) in 2013. The large proportion of the male household heads is crucial in loan decision making since men in most African societies are the decision makers [54]. The results further show that majority of the maize farmers(79.5\%) are married which implies that more consultative reasonable decisions are expected to be made by these farmers especially when it comes to the decision to take loans. Education is very important when it comes to the credit market. For farmers to be able to apply and access credit, farmers need some level of education in order to understand the contract terms [44]. However the survey data suggests a high illiteracy rate among the maize farmers as about $80 \%$ had up to Primary/JSS/Middle school or no education at all. The low level of education in this study is similar to what was reported by the GLSS6 in 2013 in which those who had no education at all stood at $19.7 \%$, those who had up to middle school and JHS were $65.5 \%$ while those had Secondary/SSS/SHS and higher were $14.7 \%$.

Unlike cocoa farming in which farmers move from other communities, towns and regions to cultivate cocoa in Ashanti and more especially Brong Ahafo region, about $70 \%$ of the maize farmers were natives of their respective localities, districts and regions. The advantage is that the farmers know each other and are ready to offer a helping hand to the other. However that does not bring competition and new ways of producing maize.

The results show that majority of the maize farmers (75. \%) do not belong to any social group that helps them to arrange for group loans. Only 25\% were members of one form or the other. Respondents who belong to associations and are able to arrange for group loans are able to reduce their transaction cost in terms of expenses on collateral and the number of times they visit the bank.

The fact that about 90 percent of the farmers are below 60 years indicates that the maize production in the two regions and mainly done by energetic and agile farmers. The aged may not be interested in maize farming because of the tedious and the speed nature of the maize production which requires the application of fertilizers and watering. About $74 \%$ of the respondents had access to the services of extension officers for at least once a month. This is expected to boost up production since farmers will receive improved technical knowhow.

\subsection{Transaction Cost Characteristics and Maize Farmers Cost of Borrowing}

Table 4 presents the averages across all the maize farmers who borrowed for various reasons and incurred the indicators of transaction costs in the table.

Per the findings, the average contracted loan size was GHÆ 2510.62 which is at a lower level than the average size of loan applied of GH4 2973.77. That is, on the average the maize farmers did not receive as much credit as they applied for. That is to say that farmers experience some level of credit rationing when they apply for the 
loans. Findings also indicate that maize farmers had to wait for a period of 4 weeks on the average to get their loans approved and disbursed after applying for the loans. Also farmers visit their banks of 4 times and spent 1.5 hours on an average before getting the proceeds of loan applied and disbursed to them. The farmers had to travel about a distance 3.22 kilometers to the lending institutions. This means the financial institutions are now closer to the farmers than it used to be in the 1980s when the outlets of banks were small, thus creating undue hardships on farmers, who often had to travel long distances or spend days at the banks to cash their checks.

Table 3. Frequency distribution of respondents according to socioeconomic characteristics and sample statistics $(\mathrm{N}=342)$

REGIONS

\begin{tabular}{|c|c|c|c|c|c|c|}
\hline \multirow[b]{2}{*}{ Characteristic } & \multicolumn{2}{|c|}{ Ashanti Region } & \multicolumn{2}{|c|}{ BrongAhafoReg } & \multicolumn{2}{|c|}{ Overall Total } \\
\hline & Number & $\%$ & Number & $\%$ & Number & $\%$ \\
\hline \multicolumn{7}{|l|}{ Gender } \\
\hline Male & 79 & 67.52 & 167 & 74.22 & 246 & 72 \\
\hline Female & 38 & 32.48 & 58 & 25.78 & 96 & 28 \\
\hline \multicolumn{7}{|l|}{ Marital Status } \\
\hline Single (divorce/separation) & 22 & 18.80 & 48 & 21.4 & 70 & 20.5 \\
\hline Married & 95 & 81.20 & 177 & 78.6 & 272 & 79.5 \\
\hline \multicolumn{7}{|l|}{ Household Head } \\
\hline Male & 96 & 82.05 & 195 & 86.6 & 291 & 85.08 \\
\hline Female & 21 & 17.95 & 30 & 13.4 & 51 & 14.92 \\
\hline \multicolumn{7}{|l|}{ Educational level of farmers } \\
\hline No education & 28 & 23.93 & 38 & 16.89 & 66 & 19.21 \\
\hline Primary/JSS/Middle school & 56 & 47.86 & 151 & 67.11 & 207 & 60.62 \\
\hline Secondary /diploma & 21 & 17.95 & 30 & 13.33 & 51 & 14.91 \\
\hline Tertiary & 12 & 10.26 & 6 & 2.67 & 18 & 5.26 \\
\hline \multicolumn{7}{|l|}{ Native } \\
\hline Yes & 85 & 72.65 & 156 & 69.33 & 241 & 70.46 \\
\hline no & 32 & 27.35 & 69 & 30.67 & 101 & 29.54 \\
\hline \multicolumn{7}{|l|}{ Age of farmer(years) } \\
\hline $18-44$ & 43 & 37.4 & 82 & 36.46 & 125 & 36.55 \\
\hline $45-60$ & 62 & 53.9 & 119 & 52.88 & 182 & 53.22 \\
\hline More than 60 & 11 & 9.7 & 24 & 10.66 & 35 & 10.23 \\
\hline \multicolumn{7}{|l|}{ Member of association } \\
\hline Yes & 26 & 22.22 & 57 & 25.33 & 83 & 24.67 \\
\hline No & 91 & 77.78 & 168 & 74.67 & 259 & 75.73 \\
\hline \multicolumn{7}{|l|}{ Extension services } \\
\hline Yes & 86 & 74 & 168 & 75 & 254 & 74 \\
\hline No & 31 & 26 & 57 & 25 & 88 & 26 \\
\hline
\end{tabular}

Source: Survey data.

Table 4. Transaction Cost Characteristics and Maize Farmers Cost of Borrowing

\begin{tabular}{|c|c|c|}
\hline Transaction characteristics & Mean & Std. Deviation \\
\hline Amount of loan Applied by farmers(GH\&) & 2973.77 & 1765.079 \\
\hline Amount Approved and contracted by farmers(GHÆ) & 2510.62 & 1998.652 \\
\hline Loan Period (in months) & 9.32 & 1.519 \\
\hline Interest Rate charged (\%) & 32.66 & 4.415 \\
\hline Distance from the Financial institution(km) & 3.22 & 2.108 \\
\hline Transportation cost per visit(back and forth ) GH\$ & 3.76 & 1.786 \\
\hline Total Transportation cost (GHc) & 12.08 & 6.1512 \\
\hline Application Fees(GHc) & 3.62 & 1.032 \\
\hline Number of visit to the Financial institution & 4.0 & .679 \\
\hline Hours Spent at Bank & 1.5 & .489 \\
\hline Time waited before the loan was approved (weeks) & 4.0 & 1.056 \\
\hline Processing fee and other paper work(GHథ) & 103.11 & 70.527 \\
\hline Collateral and guarantee cost(GHథ) & 36.45 & 29.913 \\
\hline Monitoring and supervision cost (GHథ) & 31.42 & 11.653 \\
\hline Opportunity cost & 38.94 & 8.1519 \\
\hline Legal Cost( GHథ) & 11.63 & 3.670 \\
\hline Other Cost (GH⿷) & 9.00 & 3.512 \\
\hline Total Transaction Cost(GHథ) & 246.25 & 93.7249 \\
\hline Transaction cost as a ratio of amount approved (\%) & 9.8103 & 4.3107 \\
\hline Transaction cost as a ratio of interest rate (\%) & 30.04 & 13.599 \\
\hline
\end{tabular}

Source: Survey data. 
On the average the loan repayment period or the term of contract was 9.32 months. This is closer to the 8.4 months average repayment period found by [3] Banks do not want to commit their funs in long term loan but always want to recycle the loans. Also as the period of repayment increases the probability of loan defaults increases [32]

\subsection{Components of Transaction Cost Incurred by Maize Farmers}

Borrowing transaction costs are the costs incurred by a farmer in negotiating, acquiring and repaying his loan. They are made up of both explicit and implicit costs. From Table 5, the explicit cost consists of administrative expenses and transportation cost which are made up of processing \&application fee and other paper work, transportation cost, collateral and guarantee cost Legal Cost, Monitoring and supervision cost and Other Cost. Data on these costs were obtained directly from each of the farmers. The implicit cost refers to the opportunity cost of a farmer's time in negotiating, acquiring and repaying his loan. Data on implicit costs were obtained indirectly by imputing value on the time spent by the borrowers to visit the loan office at each stage of the loan transaction. The going average farm wage rate (by day laborer wage) of GHc12.00 was used to calculate the opportunity cost of time lost as a result of applying for the loan. This was multiplied by the average number of times a farmer visited the bank to get the opportunity coast following (Olomola, 1992).

The average total transaction cost wasGH\&246.25 which was equivalent to 9.8 percent of the amount approved and contracted by farmers. The average interest rate for all the borrowers was 32.6 percent per annum (2.7\% per month). The transaction costs led to a rise of 9.8 percentage points which along with the interest rate and this increased the effective cost of obtaining credits. The ratio of transaction costs to total annual interest cost is $30 . \%$ and the average loan repayment period of 9.3 months. The cost incurred on the processing and application fees including the paper work such as photocopies and passport pictures of GHc 106.73 which constitutes $43.3 \%$ of the total transaction cost was the highest. This was followed by the opportunity cost of GHc $38.94(15.8 \%)$ and collateral and guarantee cost of GHc 36.45 which also represents $14.8 \%$. the next higher component was monitoring and supervision cost of GHc31.42 representing $12.8 \%$.

The magnitude of the farmers transaction cost can be appreciated when viewed in relation to loan amount and nominal interest rate. The processing and application fee which is the highest component of the transaction cost represents $4.25 \%$ and $13 \%$ of the loan amount and the nominal interest rates on the average respectively. The opportunity cost which follows consists of $1.6 \%$ of the approved loan amount and $4.9 \%$ of the nominal loan interest (Table 5). The total borrowing transaction cost represents $9.8 \%$ of the loan amount approved and 30\% of the nominal interest rates.

The observed transaction costs which amount to 9.8\% of the loan amount appears to be higher than the result obtained by, in his analysis of borrowing transaction costs among a sample of 150 farmers in the state of Sao Paulo, Brazil. It is also higher than the $9 \%$ results obtained by [27] in Iran but lower than the $28.32 \%$ obtained by [30] in Nigeria.

The results indicate that the financial institutions impose significant transaction costs on their clients in Ghana making the cost of credit very high

\subsection{The Effects of Relationships on Transaction Cost Incurred by Farmers}

The results of the effects of relationship lending on transaction costs are presented in Table 6. The dependent variable is the total transaction cost with the relational factors and others factors as the independent variables The Ordinary Least Square technique was employed to estimate the coefficients of the models following [27] and [30].

Table 5. Components of transaction cost incurred by maize farmers

\begin{tabular}{|c|c|c|c|c|c|}
\hline Number & Components of transaction cost & $\begin{array}{l}\text { Mean amount } \\
\text { (GHc) } \\
\text { (A) }\end{array}$ & $\begin{array}{c}\% \text { of total } \\
\text { Transaction Cost } \\
\text { (B) }\end{array}$ & $\begin{array}{l}\text { \% of Average Loan } \\
\text { amount approved } \\
\text { (C) }\end{array}$ & $\begin{array}{l}\text { \%Nominal } \\
\text { Interest rate } \\
\text { (D) }\end{array}$ \\
\hline & Explicit cost & & & & \\
\hline 1 & Processing \&application fee and other paper work & 106.73 & 43.3 & 4.25 & 13.01 \\
\hline 2 & Transportation cost & 12.08 & 4.9 & 0.48 & 1.47 \\
\hline 2 & Collateral and guarantee cost & 36.45 & 14.8 & 1.4 & 4.28 \\
\hline 3 & Legal Cost( GH⿷) & 11.63 & 4.7 & 0.46 & 1.40 \\
\hline 4 & Monitoring and supervision cost & 31.42 & 12.8 & 1.25 & 3.83 \\
\hline \multirow[t]{2}{*}{5} & Other Cost & 9.00 & 3.7 & 0.36 & 1.12 \\
\hline & Implicit cost & & & & \\
\hline 6 & Opportunity cost & 38.94 & 15.8 & 1.6 & 4.91 \\
\hline 7 & Total Average transaction cost & 246.25 & 100 & 9.8 & 30.01 \\
\hline
\end{tabular}

Source: survey data

Note; A: mean amounts of each transaction cost component, B: Percentage of total transaction cost, C: mean loan amount is GHc 2510.62, D: mean interest rate $32.66 \%$ so $D=(C / 32.66) * 100$. 
Table 6. Estimates of the effects of relationships on Transaction cost incurred by farmers

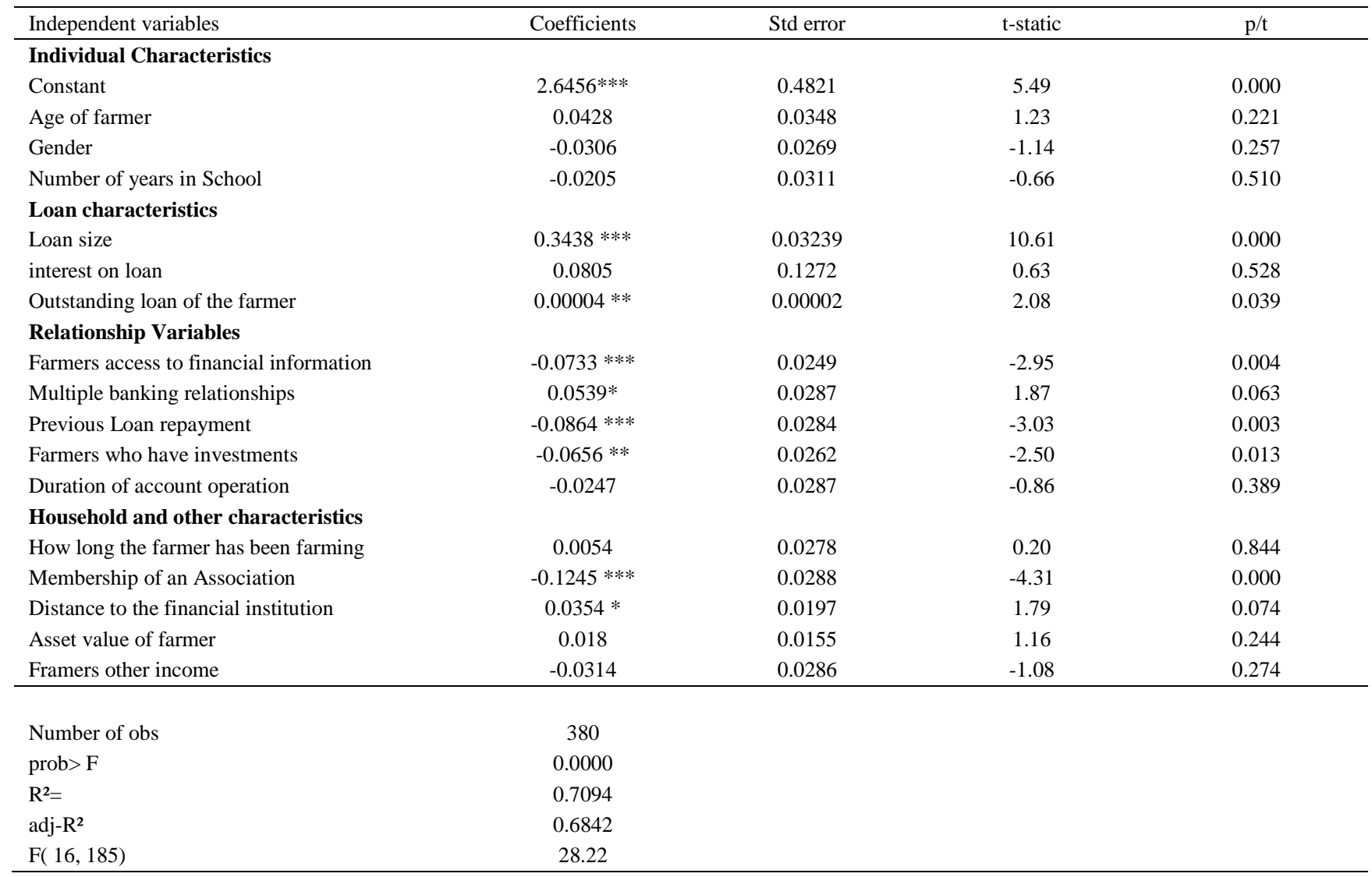

Figures in parenthesis stand for standard error (* Significant at $10 \%$; ** significant at 5\%; *** significant at $1 \%$.

The regression gave an R- squared value of 0.7094 which implies that all the explanatory variables included in the model are able to explain about 71 percent of the transaction cost incurred by the maize farmers when borrowing from financial institutions. The f statistics is also significant. It can be seen from the table (Table 6) that the distance from the farmers' house to the lending institution has a positive and significant effect at $10 \%$ on transaction costs incurred by the farmers. Many studies have confirm the fact that transaction cost increases in terms of travelling cost and opportunity cost in the form of hours spent on the journey when the distance between the house of the farmer and the bank becomes far away from each other $[27,30,35,46]$.

The loan size has positive and significant effects on the transaction costs at $1 \%$ significant level in the model. That is a one percent increase in the size of the loan increases the transaction cost by $34.38 \%$. Thus if the loan amount should increased by GHc 100.00 the transaction cost will increase by GHc 34.28. That is, farmers must incur more transaction costs in the form of collateral perfection, application fee, processing and administrative cost to obtain bigger size loans.

There is direct relationship between total transaction costs and a farmer's age. It implies that the older a farmer becomes the more costs he would likely incur in his transaction for borrowing for his farm operation. Thus from the model, a one year increase in the age of the farmer leads to $4.3 \%$ increase in the transaction cost incurred when borrowing. This is because most banks are not comfortable giving loans to the aged since they are afraid the aged could pass away at any point in time. This is in support of the findings of [30] but contradicts that of [27] who found a reverse relationship between the transaction cost and the age of the farmer.

The asset value index of the farmers bears positive effect on transaction costs. This means that the transaction costs for the wealthier people in rural areas are higher. This is because they try to go through all the process thus incurring more cost.

The coefficient of the level of education of the farmers is negative. A one year increase in the farmer's level of educations leads to $2 \%$ reduction in the transaction cost he incurs when borrowing. This implies that as the farmer advances in education, the more he gets to understand the credit process making him able to supply all needed items on time in order to get the needed loan. Also educated people are able to get closer to the bankers to request for more information that will easily help them to access the loan easily, hence the reduction in transaction cost.

The positive relationship between interest rate and the total transaction costs is worth mentioning. This means that for credit facilities with higher interest rates, borrowers had to pay more transaction costs per unit of credit. Interest on loan varies directly as transaction cost. This confirms the findings of [27].

Also banks feel reluctant to give more loans to farmers with higher outstanding loans balances because of the risk of default. That explains why there is a positive relationship between transaction cost and the outstanding loan balance of farmers in the model.

Membership of association has negative and significant effects on the transaction costs at $1 \%$ significant level in the model. This is because when farmers come together to 
jointly take a loan, on few representative arrange for the loan thereby reducing the transport cost the farmers would have incurred individually. Also the group solidarity which is used as security for the loan reduces the cost on collateral and other charges. Thus a farmer reduces his transaction cost by $13.26 \%$ (after translating the log form coefficient of 0.1245 into a real growth rate) when he become a member of association that take loan from a financial institution

One way to measure relationships is the farmer's access to the requisite financial information. The farmers access to financial information has an inverse relationship with the transaction costs of obtaining credit from the financial institutions and also significant at $1 \%$. This means that a one percent improvement in the farmers access to financial information leads to reduction of his transaction cost of borrowing by $7.61 \%$ (after translating the log form coefficient of 0.0733 into a real growth rate). This is because farmers who are interested in getting financial information from the officers of the bank may not spend more time in getting the loan since they already know what to do. Also their risk levels are well known because of the availability of information about them. They may be exempted from the pledge of collateral since they are known and that can lead to reduction in the transaction cost.

Through the use of XDS data or numerous engagements with the farmer, the bank is able to know the farmers with multiple banking relationships. From the results, multiple banking relationships is significant at $10 \%$ and directly related to the transaction cost incurred by farmers. This means that farmer with multiple banking relationships are seen to be disloyal and not trustworthy thus, they are made to spend much time at the office or visit the bank for many times before getting approval for the loans applied. Thus an increase in the number of banks the farmer deals with by one, leads to an increase his transaction cost of borrowing by $5.54 \%$ (after translating the log form coefficient 0.0539 into a real growth rate)

The previous loan repayment behavior inversely affects the transaction cost and is significant at $1 \%$. This is because Farmers who are able to pay their loans as and when the loan falls due, are seen to be trust worthy and thus do not waste time nor visit the bank on numerous coactions before getting the loans approved. Thus a one day improvement in the farmers loan repayment period (that is payment within 30 days when the repayment date falls due) increases the probability of the farmer getting reduction in transaction cost incurred (after translating the log form coefficient 0.0864 into a real growth rate) by $9.03 \%$.

Farmers who have investments (in the form of fixed deposit and treasury bills) with the bank they access loans, are able to argue for lower processing fees and are also able to get their loans approved on time without much struggle thereby reducing their transaction cost of obtaining credit. This is because if the banks decide not to reduce the processing fees, the farmers can equally decide to terminate their investments and this will affect the deposit base of the bank. This explains the negative and significant (5\%) relationship between transaction cost and investments. Thus a one cedi increase in the investments of the Farmer leads to a reduction in transaction cost by $6.79 \%$ (when the log form coefficient of 0.0656 is translated into real growth rate).
Duration of account operation has negative coefficient as expected. That is, a one year increase in farmer's number of years of account operation leads to a reduction in transaction cost by $2.51 \%$ when the log form coefficient of 0.0247 is translated into real growth rate.

\section{Conclusion and Policy Implication}

The results obtained in this study revealed that access to the requisite financial information has the potential to reduce the transaction cost farmers incur on loans.

Similarly, farmers who are able to pay their loans when the repayment date falls due are more likely to reduce the transaction cost they incur when accessing loans in addition. In the same way farmers who have investments in the form of fixed deposits also are able to reduce the transaction cost they incur. Furthermore the study found that dealing with a financial institution for a long time also has the potential to reduce the transaction cost the farmer incurs when accessing a loan. However it was found that multiple banking relationships with banks have the potential to increase the transaction cost the farmer. Also as distance between the farmer's house and the financial institution increases the transaction cost increase.

Any strategy aimed at encouraging farmers to save and invest more with their banks is recommended as a policy option for reducing transaction cost incurred by the farmers when accessing loans. Also moving from one bank to another should also be discouraged since long duration of relationships with a financial institutions helps to reduce the transaction cost on loans. However multiple banking relationships should be discouraged among farmers so as to improve their relationship with their banks and reduce the transaction cost on loans.

\section{Acknowledgments}

The authors are very grateful to all those who made valuable and helpful comments on this work especially, Dr. Aidoo, Dr. Faisal and Dr. Nicholas Oppong Mensah, all of Department of Agricultural Economics, Agribusiness and Extention, Kwame Nkrumah University of Science and Technology Kumasi, Ghana.

\section{References}

[1] Adams, D. W. and Nehman, G. I. (1978). Borrowing Costs and Demand for Rural Credit. J. Dev. Stud., 15: 165-176.

[2] Angelini, P., Di Salvo, R. and Ferri, G. (1998). “Availability and Cost of Credit for Small Businesses: Customer relationships and Credit Cooperatives”, Journal of Banking and Finance 22: 925-954.

[3] Awoke, M.U. (2004). Factors affecting loan Acquisition and Repayment pattern of small holder farmers in Ika North East of Delta State Nigeria, J. Sustainable Trop. Agric. Res. 9:61-64.

[4] Awunyo-Vitor, D. (2012). Determinants Of Loan Repayment Default Among Farmers In Ghana. Journal of Development And Agricultural Economics. Vol 4pp339-345.

[5] Bee, K. F. (2007). Rural Financial Market in Tanzania: An analysis of access to financial services in Babati District, Manyara Regio. PhD Thesis, University of South Africa.

[6] Berger, A. N. and Udell, G. F. (1995). "Relationship lending and lines of credit in small form Finance”. The Journal of business, 
Vol. 68, No.3 (Jul., 1995), pp. 351-381. Published by the University of Chicago Press.

[7] Boucher, S., and Guirkinger, C. (2007). Credit Constraints and Productivity in Peruvian Agriculture. Working papers No. 07-005 Department of Agriculture and Resource Economics, University of California, Davis, Finance Working Paper.

[8] Cole, R. A. (1998.). "The Importance of Relationships to the Availability of Credit." Journal of Banking and Finance, 22, pp. 959-977.

[9] Cuevas, C. (1988). Transaction Costs of Borrowing and Credit Rationing in Developing Countries, Economies and Sociology Occasional Paper No 1469, Agricultural Finance Program, Department of Agricultural Economics and Rural Sociology, The Ohio State University.

[10] Datta, S. K. (2003). "An Institutional Economics Approach to The Problems Of small farmer credit in India”. Centre for management in Agriculture (CMA) India Institute of management, Ahmedabad 380015.

[11] Deb, Rahul, and Tavneet Suri (2012). "Endogenous Emergence of Credit Markets: Contract-ing in Response to a New Technology in Ghana”, Forthcoming, Journal of Development Economics.

[12] Dong, F., Lu, J. and Feathersone, A. (2010). Effects of Credit Constraint on Productivity and Rural Household Income in China Selected Paper prepared for presentation at the Agricultural \& Applied Economics Association 2010 AAEA, CAES, \& W AEA Joint Annual Meeting, Denver, Colorado, July 25-27.

[13] Egaitsu, F. (1988). Measures to Reduce Transaction Costs in Farm Finance, Improved Agricultural Credit for Small Farmers in Asia and Korea, National Agricultural Cooperative Federation: 1-7.

[14] Food and Agriculture Organisation (FAO) (2012c). FAO Database. FAO, available at http://faostat.fao.org/site/617/default.aspx\#ancor.

[15] Gamin, H. (1994). Rural Credit Markets and Institutional Reforms in Developing Countries: Potential and Problems. Savings Dev., 18: 169-191. 9 .

[16] Ghana Statistical Service (2012). 2010 population and housing census Summary Statistics, Ghana Statistical Services, Accra, Ghana.

[17] Ghana Statistical Service (2005a). Socioeconomic and Demographic Trends in Ghana. Vol 1, Population Data Analysis Report.

[18] Ghana Statistical Service (2005b). 2000 population and housing census: Brong Ahafo Region: Analysis of districts data and implication for planning.

[19] Graham, D. H., Schreiner, M. and Leon, J. 1993. Transaction Costs Issues in Rural Finance: A Review of the Arguments and Recent Evidence in Asia. Transaction Costs of Farm Credit in Asia, Report of APO Seminar, $30^{\text {th }}$ November $10^{\text {th }}$ December, Tokyo, Japan. Pp.82

[20] Hosseini, S. S. and Khaledi, M. (2004). Transaction Cost of Providing Agricultural Credit for Rice Producers in Iran. The Iranian J. Food Agric. Sci., 57: 38-50. (in Persian).

[21] Hosseini, S. S., Khaledi, M., Hassanpour, E. and Ghorbani, M. (2005). Assessing Transaction Costs in Financial Markets in Rural IranResearch Project in Bank Keshavarzi, Tehran, Iran. (in Persian

[22] Hosseini, S.S., Khaledi, M., Ghorbani. M. and Brewin, D. G. (2012). An Analysis of Transaction costs of Borrowing Credit in Rural Iran, Agric Science Tech (2012) Vol. 4.

[23] Howorth, C. and Moro, A. (2006). Trust within entrepreneur bank relationships: Insights from Italy. ET\&P, 1042-2587 (C) 2006 by Baylor University.

[24] Duong, P. B. and Izumida, Y. 2002. Rural Development Finance in Vietnam: A Microeconometric Analysis of Household Surveys. World Development 30: 319-335.

[25] Gambacorta, L. (2004). How do banks set interest rates. NBER working paper series 10295

[26] Gamin, H. (1994). Rural Credit Markets and Institutional Reforms in Developing Countries: Potential and Problems. Savings Dev., 18: 169-191. 9 .

[27] Ghatak, M. (1999). Group lending, local information and peer selection. Journal of Development Economics. www.elsevier.com/locate/econbase.

[28] Husted, B.W. and Folger, R. (2004). Fairness and transaction costs: The contribution of organizational justice theory to an integrative model of economic organization. Organization science, Vil. 15, No. 6 (Nov. Dec., 2004), pp. 719-729.
[29] Igwe K.C. And Egbunson, O.M. (2013). Determinants of transaction cost of borrowers among farmers in Ikwuano Local Government Area, Abia State, Nigeria.. Department of Agricultural economics michaealokpara university of Agriculture, Umudike Abia state Nigeria.

[30] Izumida, Y. (1993). Nature of Transaction Costs in Rural Credit Delivery Systems. Transaction Costs of Farm Credit in Asia, Report of an APO Seminar, 30th November- $10^{\text {th }}$ December. Tokyo, Japan. PP.43-56.

[31] Ledgerwood, J. (1999). Microinance Handbook. Sustainable Banking with the Poor. An Institutional and Financial Perspective, The World Bank, Washington D.

[32] Levine, R. (1997). "Financial development and economic growth: Views and Agenda". Journal of economicliterature, June 1997, 35 2j ABI/INFORM GLOBAL Pg. 688.

[33] Liedholm, C. 1985. Small Scale Enterprise Credit Schemes: Administrative Costs and the Role of Inventory Norms. Working Paper No. 25, Department of Agricultural Economics, Michigan State University

[34] Llanto, G. M. 2004. Rural Finance and Developments in Philippine Rural Financial Markets: Issues and Policy Research Challenges. Philippine Institute for Development Studies. Discussion Paper Series, NO. 2004-18

[35] Masuko, L. and Marufu, L. (2003). The Determinants of Transaction Costs and Access to Credit. International Labor Organization, 20.

[36] Ministry of Food and Agriculture (2008). Agriculture in Ghana Facts and Figures, 2008 MoFA Ghana Publication.

[37] Millennium development authority- MiDA (2010) investment opportunity Ghana: maize, soya and rice Production and processinghttp://www.mida.gov.gh/mcaghana.php date accessed October 15, 2016.

[38] Millennium development authority- MiDA (2011) investment opportunity Ghana: maize, soya and rice Production and processinghttp://www.mida.gov.gh/mcaghana.php date accessed October 152016.

[39] Ministry of Food and Agriculture (2008). Agriculture in Ghana Facts and Figures, 2008 MoFA Ghana Publication.

[40] Ministry of Food and Agriculture (2009). Agriculture in Ghana Facts and Figures, 2009 MoFA Ghana Publication.

[41] Ministry of Food and Agriculture (2012). Agriculture in Ghana Facts and Figures, 2012 MoFA Ghana Publication.

[42] Ministry of Food and Agriculture (2013). Agriculture in Ghana Facts and Figures, 2013 MoFA Ghana Publication.

[43] Mpuga, P. (2008). Constraints in access to and demand for rural credit. Evidence in Uganda. A paper for presentation during the African economic conference (AEC) 12-14 November 2008 Tunis.

[44] Nalukenge, I.K. (2003). "Impact of Lending Relationships On Transaction Costs Incurred by Financial Intermediaries": A dissertation presented in partial fulfilment of the Requirements for The Degree Doctor of Philosophy in the Graduate School of The Ohio State University 2003.

[45] Nchman, G. I. (1973). Small Farmer Credit in a Depressed Community of Sao Paulo, Brazil. Ph.D. Dissertation, Department of Agricultural Economics and Rural Sociology, Ohio State University.

[46] Olomola, A.S. (1999). Determinants of Small holders Transaction costs of Procuring non-Bank Loans in Nigeria. Savings Development, 23:95-108.

[47] Petersen, M.A and Rajan, R.G. (1994). "The benefits of lending relationships: Evidence from small Business Data”. The journal of Finance. Vol. XLIX, No. 1 March 1994.

[48] Petersen, Mitchell A., and Raghuram G. Rajan, (1995). "The Effect of Credit Market Competition on Lending Relationship", Quarterly Journal of Economics, May, 407-443.

[49] Rojas, M. and Rojas, L. A. 1997. Transaction Costs in Mexico's Preferential Credit. Development Policy Review, Blackwell Publishers, Marzo, Reino Unido, 15: 1-24.

[50] Roman, L. 1994. Transaction Costs and Transition: The Case of Vietnamese Banking Sector. Savings Dev. 18:281-30625.

[51] Saito, K.A. and Villanueva, D.P.(1981)."Transaction costs of credit to the small-scale sector in the Philippines". Economic Development and Cultural change, Vol. 29, No. 3 (Apr., 1981), pp. 631-640. Published by: The University of Chicago Press. 
[52] Shankar, S. (2007). Transaction costs in group microcredit in India. Management decision.Vol.45, No.8, 2007, pp. 1331-1342. Emerald Group Publishing Limited.

[53] Sharpe, S. (1990). Asymmetric information, bank lending and implicit contracts: astylized model of customer relationships, Journal of Finance, 45, 1069-108

[54] Turkson, P. K., and Naandam, J. (2006).Constraints to ruminant production in East Mamprusi Districts of Ghana. Ghana Journal of Agriculture Science, 39, 155-164.

[55] Udoh E. J. (2005)." Demand and Control of Credit Form Informal Sources by Rice Producing Female of Akwa Ibom State, Nigeria”. Journal of Agriculture and Social Sciences. Vol. 1 (2) Pp.152-155.

[56] Untalan, T. and Cuevas, C. 1989. Transaction Cost and the Viability of Rural Financial Intermediaries. J. Philippine Dev., 16:37-87.
[57] Williamson, O.E. (2007). Transaction Cost economics: An Introduction. Economics discussion papers.2007-3, march 1, 2007 Economic sociology. CSES working paper series, paper \# 13 October 2003.

[58] World Bank (1975). Agricultural credit sector policy Review. World Bank, Washington DC.

[59] World Bank, (2008). Food safety task force, final draft, Republic of Ghana. Africa Agriculture and Rural Development (AFTAR) and Ministry of Food and.

[60] Yedra, R. (1993). The Rural Credit System in the Philippines: Current Situation and Policy Measures. Transaction Costs of Farm Credit in Asia, Report of APO Seminar, 30thNovember$10^{\text {th }}$ December, Tokyo, Japan. PP.208-221.

[61] Zeller, M. (1994). "Determinants of Credit Rationing: A Study of Informal Lenders and Formal Credit Groups in Madagascar." World Development, 22 (12), pp. 1895-1907. 